\title{
The History Continues: Reflections About the Theory of the End of History From Francis Fukuyama
}

\author{
Sabri Kiçmaria
}

\begin{abstract}
Fukuyama's thesis about "the end of history" is controversial. History is not an ideology. History cannot be ended, if by history we mean the past, which we remember and interpret for the purpose of orientating ourselves in the present and the future. Fukuyama has a right to declare the victory of liberal democracy, but other political ideologies have not become extinct. If we look at the thesis of the "end of history" from a scientific point of view, then we can conclude that such a thing is impossible: for after the "end of history", history continues. Therefore, there is no real end to history. It is continuing a quarter of a century after the Fukyama's thesis was published. Even if we can accept the thesis of the end of history as an ideology, we still cannot accept the end of philosophy. Phenomenology, Critical Realism, Existentialist Philosophy, Hermeneutics, Structuralism, etc. are just some of the evidence that contemporary philosophy continues to exist and evolve, despite the rising and falling of various ideologies in the twentieth century and the early twenty-first century. This can also be said about art, culture, and history as a science.
\end{abstract}

\section{Keywords}

Philosophy, history, ideology, religion, democracy

In the summer of 1989, the American political scientist Francis Fukuyama published his famous essay “The End of History?” in the prestigious American magazine The National Interest. Between the summer of 1989 and 1992, developments took place which testify to the accuracy of Fukuyama's thesis as presented in his article. His book The End of History and the Last Man was published after the collapse of communism. Fukuyama's article was published too late to warn about the beginning of the communist fallout in the USSR (Union of Soviet Socialist Republics) and Eastern Europe. Fukuyama himself does not see himself as a "warner". He even writes that the collapse of communism was almost completely unforeseen (Fukuyama 2006: 8).
Fukuyama proclaims the ideological victory of liberal democracy and the free market system over monarchy, fascism, and communism. He concluded in his article in 1989:

The end of history will be a very sad time. The struggle for recognition, the willingness to risk one's life for a purely abstract goal, the worldwide ideological struggle that called forth daring, courage, imagination, and idealism, will be replaced by economic calculation, the endless solving of technical problems, environmental concerns, and the

aEmbassy of the Republic of Kosovo in Australia, Australia

Correspondent Author:

Sabri Kiçmari, Unit 5/317 Goyder Street, Canberra ACT 2604, Australia 
satisfaction of sophisticated consumer demands. In the post-historical period there will be neither art nor philosophy, just the perpetual care taking of the museum of human history. (Fukuyama 1989: 17)

In an article published five years later, Fukuyama responds to his critics that the notion of the "end of history" is fundamentally normative rather than descriptive. The "end of history" is not defined by the short-run unfolding of contingent events, but by its normative nature.

If the question is asked "Have the events of the past few years (the Gulf War, Bosnia, Somalia and so on) made you rethink the hypothesis?” the answer is obviously no... Fascism may be winning politically in Serbia, but no one (even, I would guess, in Belgrade) sees Serbia as an attractive generalizable model for the future. (Fukuyama 1995: 31)

Fukuyama's thesis about "the end of history" is controversial. This phrase, as he says, is not his own, but is sourced from Hegel and Marx. In fact, in both Hegel's and Marx's concepts, the phrase is about the end of history as an ideology, brought about by the most advanced version of the state system.

However, the question arises: has history really ended with the fall of the socialist systems in Eastern Europe? The phrase that Fukuyama has chosen for his book is not adequate. History is not an ideology. History cannot be ended, if by history we mean the past, which we remember and interpret for the purpose of orientating ourselves in the present and the future. Fukuyama has a right to declare the victory of liberal democracy, but other ideological variations have not become extinct. After the "end of history", history continues. Therefore, there is no real end of the history. History has not finished: it is continuing a quarter of a century after the Fukyama thesis was published.

\section{RESEARCH METHODOLOGY}

The hermeneutic method is a method of the analysis of the "theory of the end of history". This method is a systematic and practical way of understanding the history in a reflective manner. Hermeneutic is a comprehensive understanding method (Veraart and Wimmer 2008). To achieve the goal of the analysis of the theory of Fukuyama, it was a need of an explanation of the understanding of the history by Hegel, Marx, and Kojève, which was based on the hermeneutic methods of description, understanding, and explanation (Denzin 2009). The hermeneutic method focuses on describing the main concepts of Fukuyama, taking into account their political, ideological, economic, and cultural frameworks. The conclusions that can be drawn from the described method previously considered the analytical basis of the phenomenon of history.

\section{RELEVANT THEORY}

The analysis of the theory of the end of history refers to the theory of realism in international relations. The theory of realism assumes that sovereign nation-states strive for power and are the most important actors, that the international system is anarchic, that states cannot act according to individual morality, and that the power is a zero-sum game on the international level (Morgenthau 1978). The main representatives of realism are Hans Morgenthau and Henry Kissinger. According to representatives of realism, the greatest political injustice is when nations presume to declare their concept of morality as universal.

\section{PESSIMISM OF THE TWENTIETH CENTURY: NAZI-FASCISM AND COMMUNISM}

Fukuyama finds that the nineteenth century optimism was followed by the pessimism of the twentieth century. Pessimism has its basis in the two world wars. The twentieth century was characterized by an inhumane sliding of state and political systems 
towards totalitarianism. So both the extreme right (Nazi-fascism) and the extreme left (Communism) managed to create their undemocratic and aggressive political ideologies. Nazi-fascism tried "to establish a coherent, right-wing, non-democratic, non-egalitarian principle of legitimacy" that denied human rights and equality among the population, considering the "ultimate source of legitimacy" to be based on race and culture, and proclaiming the Germans as a "master race" which should rule other people (Fukuyama 2006: 16). Soviet totalitarianism aimed to extend full control over the lives of citizens; it sought to destroy civil society, opposition political parties, the press, trade unions, private enterprises, and religious institutions; it sought to do this by the means of changing societal values and beliefs through structured state control of the press, education, and propaganda, and by means of weakening the role of the family in order to create a "new Soviet man" (Fukuyama 2006: 24).

American scholars Carl Joachim Friedrich and Zbigniew Brzezinski in their analysis of the fundamental features of totalitarian dictatorship count six elements of a totalitarian state. One of them is the full control of the economy (Friedrich and Brzezinski 1999: 231). Hannah Arendt thinks similarly about the features of totalitarianism (Arendt 1986: 958) as well as the author's honored professor, Manfred Funke (Funke 1999: 152). Communism is a totalitarian dictatorship system. It has not been completely demolished as Nazi-fascism was. It is still preserved in the People's Republic of China, Vietnam, North Korea, Cuba, and Laos.

Communism has remained strong in the People's Republic of China, the country with the largest population in the world, despite radical transformations in the economic sphere. But what we can fully agree on with Fukuyama is the fact that communist power "has ceased to reflect a dynamic and appealing idea” (Fukuyama 2006: 33). He also warned in time about the consequences of the collapse of communism: the risk of its replacement "by nationalist authoritarianism, or perhaps even by fascism of the Russian or Serbian variety" (Fukuyama 2006: 36). This Fukuyama's conclusion, written in 1992, turned out to be very predictive: Milosevic's Serbia caused four wars (against Slovenia, Croatia, Bosnia-Herzegovina, and Kosovo) within seven years (1992-1999) with tragic consequences for hundreds of thousands of people, while Putin's Russia effectively invaded Chechnya and Crimea, and is keeping specific regions of Georgia (South Ossetia and Abkhazia), eastern Ukraine, Moldova (Transnistria), etc. in de facto warfare.

\section{THEORETICAL ENTWINE OF FUKUYAMA WITH KANT, HEGEL, AND MARX}

Fukuyama explains that his thesis about the end of history does not mean the occurrence of events, but he understands history "as a single, coherent and evolutionary process" (Fukuyama 2006). He entwines his thesis with the concepts of Kant, Hegel, and Marx.

The greatest advances in the writing of universal history according to Fukuyama belong to representatives of the German idealist tradition: Kant and Hegel. Kant also predicts that history will have an end. The end, according to him, is achieved by the realization of human rights and freedoms. Hegel writes that "world history is the progress in consciousness of freedom” (Hegel 1961: 61). Hegel understands history as human progress towards a higher degree of rationality and freedom. But he did not believe in the endless continuation of the historic process. He was convinced that there is an end to history (Hegel 1961: 64). He even declared the end of history after the Battle of Jena in 1806.

All of Fukuyama's book is subtly influenced by Hegel, according to Alexander Kojève's interpretation. Kojève agrees with Hegel that the end of history comes with democratic revolution. But Kojève is too radical in his theoretical conclusions. He thinks that 
the end of history is not just the end of great political battles and conflicts, but also the end of philosophy (Fukuyama 2006: 67). We still cannot accept the thesis of the end of philosophy. Phenomenology, Critical Realism, Existentialist Philosophy, Hermeneutics, Structuralism, etc. are just some of the evidence that contemporary philosophy continues to exist and evolve, despite the rising and falling of various ideologies in the twentieth century and the early twenty-first century. This can also be said about art, culture, and history as a science.

Among Hobbes, Locke, and Hegel, Fukuyama chooses the latter. First, according to him, Hegel gives us a more noble sense of liberalism than Hobbes and Locke, and secondly, Hegel's concept of history as "a struggle for recognition" is very useful in understanding the contemporary world. Hegel's first man is distinguished from the animals not only through his desire for real "positive" objects, but still more so by his desire for such objects that are totally immaterial: "Above all, he desires the desire of other men, that is, to be wanted by others or to be recognized” (Fukuyama 2006: 26).

Fukuyama writes that Hegel and Marx both held the view that primitive society was divided into social classes. In this, Fukuyama is not fully accurate. Marx and Engels defended the view that the primitive first community should have been a kind of society without classes, an initial form of social and political organization in which common ownership was applied to the necessary resources (Engels 1975). Only with the creation of private property, came the accumulation of capital and the exploitation of slave labor in the slave society that resulted in the creation of classes, according to Marx. However, the nature of the classes according to Hegel, is not identical to that of Marx: for Hegel, class differences did not arise from the economic nature of a primitive community. The society was divided between the patrons, who were willing to risk their life for recognition and prestige, and the slaves who were unable to do so.
Fukuyama defends the view that on this point, Hegel is more accurate than Marx (Fukuyama 2006: 147).

\section{THE FIRST MAN AND THE LAST MAN}

Hegel's "first man" in "Phenomenology of Spirit" lived at the beginning of history and his philosophical function was indistinguishable from Hobbes, Locke, and Rousseau's "man in the state of nature". According to Hegel, the potential of slave freedom is historically more important than that of the master. The slave does not recognize freedom, he can only imagine it. Freedom for him is abstract. So his idea of freedom is more philosophical. And the slave has revealed to us his desire for freedom and recognition. This desire is the engine that has driven the history forward, and not the complacency and static identity of the master. While the struggle for recognition caused the first bloody battle between people, history has come to an end because the universal and homogenous state has realized mutual recognition and fulfilled this great desire of the man. Thus, the slave has realized his freedom.

Fukuyama writes that the revolutionaries who fought against Ceausescu's Securitate in Romania, the brave Chinese students who stood in front of Tiananmen Square tanks, and the Lithuanians who fought against Moscow for their independence (Fukuyama 2006: 312)—we would add the Albanians who fought for their freedom in Kosovo-are the most free and most humane people. They changed their status from slaves to free people, risking their lives in bloody battle.

The last man according to Fukuyama is a creature that will be born at the end of history. He describes the last man as an individual who puts self-defense before everything. Even in this post-historical state, he resembles Hegel's slave in the initial battle of history. However, he has now the historical experience, which is characterized by wars, evolutions, and revolutions, of which he has become tired throughout history. The 
last man therefore moves towards the end of his history, towards liberal democracy. His experience has taught him not to risk his life "in vain battles" and "in vain prejudices". So the end of history will be the end of bloody war and bloody revolutions. People will not have to fight anymore. They will meet their needs through economic activity.

\section{FUKUYAMA'S CONCEPTS ON RELIGION AND NATIONALISM}

Fukuyama finds that most of today's democracies are Christian countries. But religion defines neither democracy per se nor free society. Even today, there are Christian countries, which are dominated by terrible authoritarianism, as there are many states with a non-Christian religion that are democratic and tolerant (Freedom House 2016).

Fukuyama notes more than once that there is no longer any universal ideology that can challenge liberal democracy. Democratic revolutions involving Islamic countries in 2011, discharged the idea of Islamic societies that were untouched by the liberal revolution. The process of social transformation in North Africa and the Middle East is still underway. In addition to the penetration of a powerful spirit of liberal democracy in these countries, one of the toughest variants of Islamic extremism-Islamic fundamentalism -is being reborn. But Islamism is unlikely to spread beyond Islamic cultural regions. It remains to be seen whether the conclusion of democratic processes in North Africa and the Middle East will empower the liberal democratic or the radical Islamic spirit.

Fukuyama writes that nationalism is a manifestation of desire for recognition. It aims to replace the master's relationship to the slave with a mutual recognition of equality. He does not distinguish nationalism from patriotism. The dignity that patriotism suggests is universal, national, and human; but nationalism only recognizes the right of its national or ethnic community. Nationalism leads to potential conflict with other nations, which also seek recognition of their dignity, while patriotism seeks mutual respect among the nations.

Fukuyama defines the European Union (EU) as a union of national states, as a European United Nations of national states. With this, he points out not only the strong national identity of the EU countries, but also predicts the "end of history" in the United Europe of national states. He is completely right at this point. The EU is a structure of national states and not a confederation that would aim to eradicate those nations. The United Kingdom referendum to leave the EU in 2016 and referendums in the Netherlands and France for European Constitution in 2005 testify that nations want to preserve their identity. New states emerging from the Soviet Union, Yugoslav Federation, and Czechoslovakia have entered the EU not to merge their nations, but to become part of the United Europe as equal nations. The EU Constitution project failed precisely with regard to the national issue. The criticism was based on the idea of creating a "super state".

\section{CONCLUSIONS}

Fukuyama responds to accusations of reductionism that:

Any attempt to construct a universal history necessarily involves a high degree of abstraction and simplification from the enormous mass of empirical historical facts, and therefore will always be open to charge of reductionism. Much of my book was implicitly an attack on the economic reductionism of Marxism and an attempt to cover the greater richness of human motivation embodied in the concept of the struggle for recognition. (Fukuyama 1995: 41)

Fukuyama uses a Marxist method to prove the end of communism. This made him an extraordinary object of criticism from all ideological directions. It is 
easy to notice a number of contradictions in the text. For example, on the one hand, he finds that for societies with a leading class, or national or religious polarization, democracy is not the best option for resolving conflicts among class, ethnic, and national groups. According to him, a modern system of dictatorship can be in principle more effective than democracy for the creation of preconditions that would allow capitalist economic growth and the establishment of a stable democracy (Fukuyama 2006: 119). On the other hand, he writes that class, national, ethnic, and religious tensions can be more easily alleviated in a system of liberal democracy (Fukuyama 2006: 121).

Another contradictory example is his finding that empirical evidence proves that market-oriented authoritarian modernizers do better economically than their democratic counterparts (Fukuyama 2006: 123). Yet, shortly afterwards, Fukuyama writes that there is an unquestionable relationship between economic development and liberal democracy; and liberal democracy is compatible with industrial maturity and is preferred by the citizens of many industrially advanced countries (Fukuyama 2006: 125).

Samuel P. Huntington has formulated the toughest criticism against Fukuyama's thesis. Huntington defends the view that the main source of the post-Cold War order will not be ideological, or economic, but cultural: "Nation states will remain the most powerful actors in world affairs, but the principal conflicts of global politics will occur between nations and groups of different civilizations. The clash of civilizations will dominate global politics. The fault lines between civilizations will be the battle lines of the future" (Huntington 1993: 22).

Fukuyama describes the EU as a project to build a home for the last man, who will appear at the end of history. Developments in the EU since the publication of Fukuyama's book have been twofold: in favor and contrary to Fukuyama's thesis. The number of EU member states has risen from 12 countries to 28 member states, and the potential candidature has opened for six Southeast European countries (Albania, Bosnia-Herzegovina, Kosovo, Macedonia, Montenegro, and Serbia) to join the EU. The common currency has been approved and a number of national laws have been aligned to those of the EU. But at the same time, referendums have failed in the Netherlands and France for amendments of the EU Constitution, and the United Kingdom is in the process of leaving the EU after the referendum of June 23, 2016. The future of this last man model is still insecure.

\section{References}

Arendt, H. 1986. Elemente und Ursprünge totaler Herrschaft: Antisemitismus, Imperialismus, totale Herrschaft (Elements and Origins of Total Rule: Anti-Semitism, Imperialism, Total Rule). München: Piper Taschenbuch.

Arnold, J. H. 2000. History: A Very Short Introduction. Oxford: Oxford University Press.

Denzin, N. K. 2009. The Research Act: A Theoretical Introduction to Sociological Methods. New Jersey: Rutgers.

Derrida, J. 1994. Specters of Marx: State of the Debt, the Work of Mourning and the New International. New York and London: Routledge.

Engels, F. 1975. Der Ursprung der Familie, des Privateigenthums und des Staats (The Origin of the Family, Private Property, and the State). Berlin: Dietz Verlag.

Esping-Andersen, G. 1990. The Three Worlds of Welfare Capitalism. New Jersey: Princeton University Press.

Freedom House. 2016. Freedom in the World-Report 2016. Retrieved (https://freedomhouse.org/sites/default/files/FH_ FITW_Report_2016.pdf).

Friedrich, C. J. and Z. Brzezinski. 1999. "Die allgemeinen Merkmale der totalitaeren Diktatur" (The General Characteristics of the Totalitarian Dictatorship). In Totalitarismus im 20. Jahrhundert. Eine Bilanz der internationalen Forschung (Totalitarianism in the 20th Century. A Balance Sheet of International Research), edited by E. Jesse. Bonn: Bundeszentrale für politische Bildung.

Fukuyama, F. 1989. “The End of History?” The National Interest, Summer 1989.

- 1995. "Reflections on the End of History, Five Years Later.” History and Theory 34(2):27-43.

- 2006. The End of History and the Last Man. New York, London, Toronto, Sydney: Free Press.

- 2016. Demokratie stiftet keine Identität-Ist das Modell des Westens am Ende (Democracy Does not Create 
Identity - Is the Model of the West at the End)? DIE ZEIT. Retrieved (https://www.zeit.de/2016/13/francis-fukuyamapolitikwissenschaftler-populismus-usa).

Funke, M. 1999. "Brauen und rote Diktaturen-Zwei Seiten einer Medaille?: Historikerstreit und Totalitarismustheorie” (Brewing and Red Dictatorships-Two Sides of a Medal?: Historian Disputes and Totalitarianism Theory). Totalitarismus im 20. Jahrhundert. Eine Bilanz der internationalen Forschung (Totalitarianism in the 20th Century. A Balance Sheet of International Research), edited by E. Jesse. Bonn: Bundeszentrale für politische Bildung.

Hegel, G. W. F. 1961. Philosophie der Geschichte (Philosophy of History). Stuttgart: Taschebuch.

- Grundlinien der Philosophie des Rechts oder Naturrecht und Staatswissenschaft im Grundrisse (Principles of the Philosophy of Law or Natural Law and Political Science in the Floor Plans). Frankfurt: Taschenbuch.

Hobbes, T. 1996. Leviathan oder Stoff, Form und Gewalt eines bürgerlichen und kirchlichen Staates (Leviathan or the Matter, Forme and Power of a Common-Wealth Ecclesiasticall and Civil). Berlin: Akademisches Verlag.

- 2014. Leviathan. Edited by N. Malcolm. Oxford: Oxford University Press.

Huntington, S. P. 1993. “The Clash of Civilisations?” Foreign Affaires, Summer 1993.

Jaeschke, W. 2003. Hegel-Handbuch (Hegel Handbook). Stuttgart: Metzler.

Jesse, E. 1999. Totalitarismus im 20. Jahrhundert. Eine Bilanz der internationalen Forschung (Totalitarianism in the 20th Century. A Balance Sheet of International Research). Bonn: Bundeszentrale für politische Bildung.

Kant, I. 2003. To Perpetual Peace: A Philosophical Sketch. Indianapolis: Hackett Publishing.

Kojève, A. 2000. Outline of a Phenomenology of Right.
Lanham: Rowman \& Littlefield Publishers.

- 2014. "Interpretation of the General Introduction to Chapter VII (The Religion Chapter of Hegel's Phenomenology of Spirit).” Translated by I. A. Moore. Parrhesia: A Journal of Critical Philosophy 20:15-39.

Locke, J. 1988. Two Treatises of Government. Cambridge: Cambridge University Press.

Marx, K. and F. Engels. 1976. Manifest der Kommunistischen Partei (The Communist Manifesto). Berlin: Dietz Verlag.

Morgenthau, H. J. 1978. Politics Among Nations: The Struggle for Power and Peace. New York: Alfred A. Knopf.

Rousseau, J.-J. 1997. The Social Contract' and Other Later Political Writings. Translated by V. Gourevitch. Cambridge: Cambridge University Press.

Taylor, C. 1995. “Aneinander vorbei: Die Debatte zwischen Liberalismus und Kommunitarismus” (Beyond Each Other: The Debate Between Liberalism and Communitarianism). In Kommunitarismus. Eine Debatte über die moralischen Grundlagen moderner Gesellschaften (Communitarianism. A Debate About the Moral Foundations of Modern Societies), edited by A. Honneth. Frankfurt am Main: Campus Verlag.

Veraart, A. and R. Wimmer. 2008. "Hermeneutik” (Hermeneutics). Pp. 364-367 in Enzyklopädie Philosophie und Wissenschaftstheorie (Encyclopedia Philosophy and Theory of Science), edited by J. Mittelstraß. Stuttgart: Metzler.

\section{Bio}

Sabri Kiçmari, Ph.D., sociologist, philosoph, and political scientist, ambassador of the Republic of Kosovo in Australia, Canberra; research fields: political philosophy, theory of diplomacy, political sociology, and social structure. 